\title{
Quinolinic Acid
}

National Cancer Institute

\section{Source}

National Cancer Institute. Quinolinic Acid. NCI Thesaurus. Code C113236.

An intermediate product of the kynurenine pathway, which is responsible for the conversion of the amino acid tryptophan into nicotinamide adenine dinucleotide, with potential neurotoxic activity. If produced in excess, quinolinic acid can cross the bloodbrain barrier (BBB) and function as an N-methyl-D-aspartate (NMDA) receptor agonist, which may lead to both neuronal damage and neurodeg enerative brain disease. The NMDA receptor, a heterotetrameric, ligand-gated and voltage-dependent glutamate receptor, is critical for synaptic plasticity, learning and memory. 